\title{
DIAMONDS FROM SESE AND MUROWA KIMBERLITES (ZIMBABWE) - EVIDENCE OF EXTREME PERIDOTITIC LITHOSPHERE DEPLETION AND TI-REE METASOMATISM
}

\author{
Bulanova* GP ${ }^{1}$, Marks A. ${ }^{1}$, Smith $\mathrm{CB}^{1}$, Kohn $\mathrm{SC}^{1}$, Walter $\mathrm{MJ}^{1}$, Gaillou $\mathrm{E}^{2}$, \\ Shirey SB ${ }^{2}$. Trautman R. ${ }^{3}$ and Griffin B.J. ${ }^{4}$ \\ 1. School of Earth Sciences, University of Bristol, United Kingdom \\ 2. Department of Terrestrial Magnetism, Carnegie Institution of Washington, Washington D.C., USA \\ ${ }^{3}$. Perth, Western Australia, ${ }^{4}$. University of Western Australia, Perth \\ *corresponding author (galina_bulanova@hotmail.com)
}

\section{INTRODUCTION}

The extreme depletion of the Zimbabwe subcratonic lithospheric mantle makes it an attractive target for research into processes of craton formation and evolution. We have studied comprehensively 350 diamonds and their syngenetic inclusions from the Cambrian-aged Murowa and Sese kimberlites to compare the implied nature of the Paleoarchean mantle at the time of diamond formation with published information from Mesoarchean mantle xenoliths from these same pipes (Smith et al., 2009). To constrain the process of diamond formation the nitrogen $(\mathrm{N})$ content and aggregation were investigated in corerim traverses of the diamonds together with study of compositional changes in mineral inclusions. This provides information on the relationships in time and space between extreme depletion and Ti-REE metasomatism events in the Zimbabwe lithospheric mantle.

\section{GEOLOGICAL SETTING}

Murowa and Sese kimberlites (Smith et al., 2004) form two clusters of diamondiferous pipes, sills and dykes $60 \mathrm{~km}$ apart and are located near the southern edge of the Zimbabwe Craton (Fig. 1). To the south, within the Limpopo Mobile Belt, are the Cambrian-aged pipes of Venetia, River Ranch, Mwenezi and Chingwisi. Sese Pipe K1 was dated at $538 \mathrm{Ma} \pm 11$ (Rb-Sr mica isochron, Smith et al., 2004).

Mantle xenoliths from the Murowa and Sese kimberlites (Smith et al., 2009) were found to be dominated by highly depleted dunites, lacking the effects of the later silicic metasomatism that led to the introduction of orthopyroxene in the Kaapvaal Cratonic lithospheric mantle. Whole rock Re-Os analyses of mantle xenoliths gave an

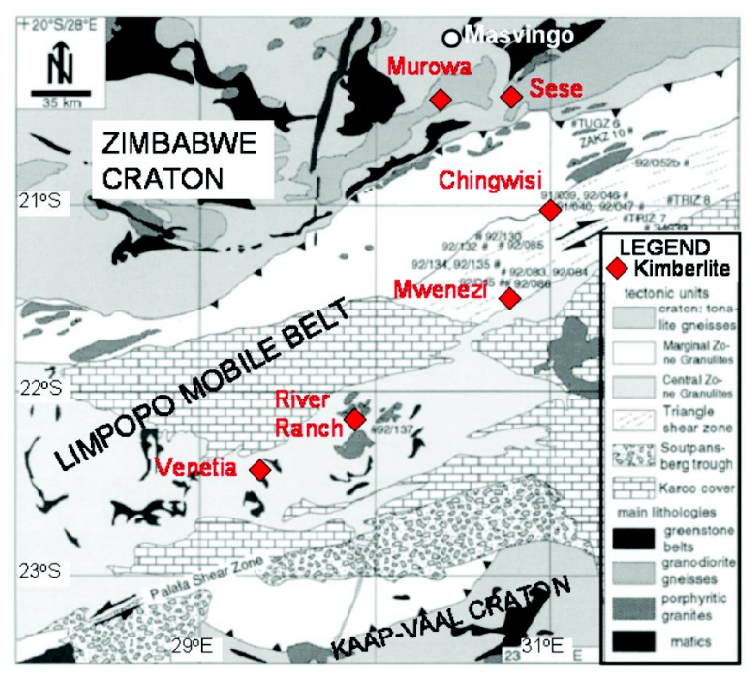

Fig 1. Location of Murowa, Sese and adjacent kimberlites, in relation to the Zimbabwe Craton, Limpopo Mobile Belt and Kaapvaal Craton (after Kamber et al., 1995; Smith et al., 2009). 


\section{0 $^{\text {th }}$ International Kimberlite Conference, Bangalore - 2012}

average Re-Os model age of $3.2 \mathrm{Ga} \mathrm{T}_{\mathrm{MA}}$ (Smith et al., 2009).

\section{SAMPLES AND METHODS}

The diamonds are dominantly colourless or pale brown octahedra, with lesser dodecahedra or transition forms. Pseudohemimorphic shapes also occasionally occur. All inclusions selected for study have diamond-imposed morphology, no cracks going to the crystal surface and are therefore considered syngenetic. The diamonds were cut by a laser at the Carnegie Institution, Washington, and/or polished along two parallel dodecahedral planes so that central parallel plates or sections were made and inclusions exposed.

The internal structure of the diamonds was studied by $\mathrm{CL}$ imaging. $\mathrm{N}$ content and aggregation in 26 parallel diamond plates from Sese and 16 from Murowa were determined in core-rim profiles using a SpectraTech infrared microscope coupled to a Nicolet Nexus FTIR at University of Bristol and Bruker instrumentation at University of Western Australia. Mineral inclusions were analyzed in situ by electron microprobe. Trace element concentrations of silicate inclusions were determined using a Cameca IMS-4f ionmicroprobe at the Edinburgh Ion Microprobe Facility (EIMF). Core-rim study of carbon isotope composition of one diamond was also acquired at the EIMF with a Cameca ims 1270, using a $\sim 6$ nA primary ${ }^{133} \mathrm{Cs}^{+}$beam.

\section{RESULTS}

\section{Diamond internal structures}

Most of the studied diamonds $(90 \%)$ have simple octahedral zonation (Fig. 2a, 2d) and blue CL-colour. Less common is cubic or cubooctahedral growth in the cores (Fig. 2b \& c). Many stones show features of plastic deformation expressed by a net of slip lines (Fig 2a-c) yellow in CL.

\section{Nitrogen content and aggregation}

The diamonds from Sese contain moderate $\mathrm{N}$ concentration (300-700 ppm, median value 377 $\mathrm{ppm}$ ) with medium to high degrees of $\mathrm{N}$ aggregation (mostly $40-70 \% 1 \mathrm{aB}$, median value $48 \%$ ). Defects due to hydrogen are prominent. Several crystals recorded $100-500 \mathrm{ppm} \mathrm{N}$ in a highly aggregated state (80-95\% of type $1 \mathrm{aB})$. Core-Rim profiles in individual diamonds generally show gradually decreasing $\mathrm{N}$ content and slightly diminishing aggregation and hydrogen $(\mathrm{H})$ concentration.

Murowa diamonds have a wider $\mathrm{N}$ range ( 15 $-1250 \mathrm{ppm}$ ) but with the majority of values (200 to $700 \mathrm{ppm}$, median $386 \mathrm{ppm}$ ) similar to Sese. The diamonds are generally well aggregated (20$80 \% \mathrm{IaB}$, median value $58 \%$ ), with cores of $>50 \%$ $1 \mathrm{aB}$ and also show small decreasing $\mathrm{N}$ contents and aggregation from core to rim. $\mathrm{H}$ peaks are prominent, with concentration decreasing from core to rim, correlating with $\mathrm{N}$ content and aggregation.
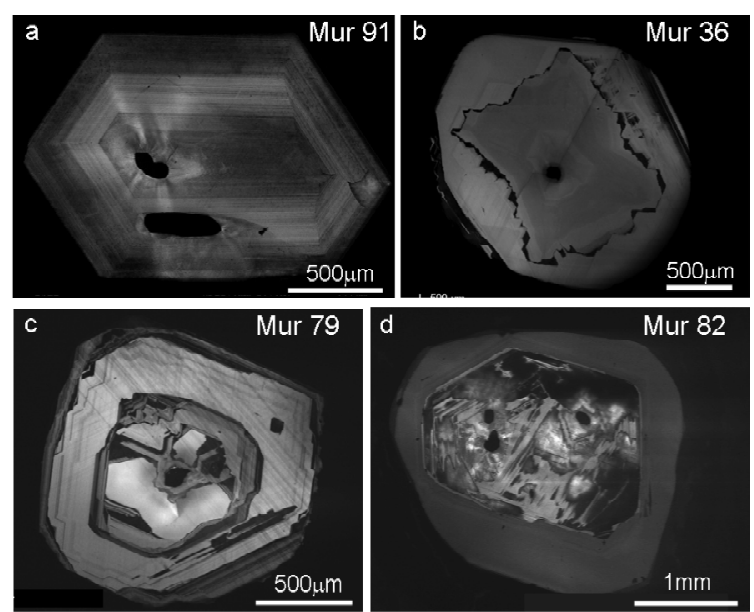

Fig. 2. CL images of polished plates showing internal structure of the diamonds. (a) Diamond of octahedral zonation with plastic deformation and chromite and Cr-pyrope inclusions; (b) Cube $\rightarrow$ cubo-octa $\rightarrow$ octahedron zonation; chromite inclusion-seed; (c) Sectorial (cubo-octa) $\rightarrow$ octahedron + plastic deformation; olivineseed. (d) Octahedral core with multiple inclusions of olivine, chromite, Cr-pyrope and octahedral rim without inclusions + resorption $\rightarrow$ octa/dodecahedron. 


\section{0 $^{\text {th }}$ International Kimberlite Conference, Bangalore - 2012}

Three Murowa diamonds show sharp corerim $\mathrm{N}$ content and aggregation zonation, in complete agreement with their internal structure. Thus Mur-82 diamond core (Fig. 2d) has 1200 ppm $\mathrm{N}$ which is $82 \%$ aggregated, but the rim zone has $1087 \mathrm{ppm} \mathrm{N}$ with only $16 \%$ aggregation.

\section{Composition of the inclusions}

Diamond inclusion parageneses are $\sim 99 \%$ peridotitic, predominantly dunite-harzburgite, with $<1 \%$ eclogitic.

\section{Peridotitic paragenesis}

Chromite and olivine, found not only as single phases but also as inclusions in each other, and Ni-rich sulphides are the most abundant (Fig. 5) inclusions in the diamonds. Cr-pyrope and orthopyroxene are very rare. Yimengite and armalcolite inclusions were identified but are rare. A single inclusion of Cr-diopside occurs inside an olivine inclusion from one diamond, indicating lherzolitic paragenesis.

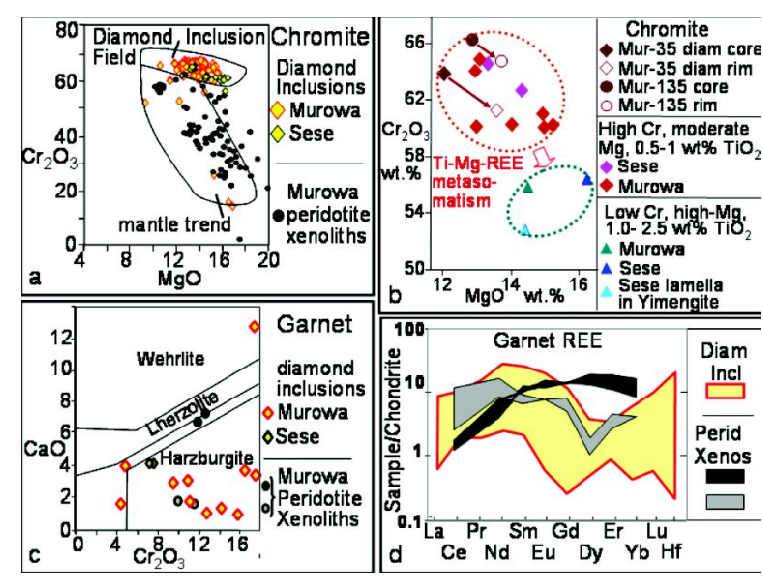

Fig. 3. Mineral inclusion compositions in Murowa and Sese diamonds. (a) chromite from diamonds contrasted with those from peridotite xenoliths; (b) chromite chemistry trends from diamond cores to rims; fields for low- and high-Ti chromites are also shown; (c) $\mathrm{CaO}$ and $\mathrm{Cr}_{2} \mathrm{O}_{3}$ content for Cr-pyrope from diamonds compared to those from peridotite xenoliths, (d) Cr-pyrope chondritenormalised REE compositions for inclusions in diamonds compared to those for pyrope from peridotite xenoliths.
Chromites mainly have compositions typical of world-wide chromite diamond inclusions (Fig. 3a). In contrast, many spinels from the peridotite xenoliths are of secondary origin and are lower in $\mathrm{Cr}$ (Smith et al, 2009).

A small group of the diamond inclusion chromites are characterized by elevated $\mathrm{Ti}$ and corresponding lower $\mathrm{Cr}$ (Fig. 3b). The main lowTi group contains $\mathrm{Cr}_{2} \mathrm{O}_{3} 61-67 \mathrm{wt} \%, \mathrm{MgO} 12-15 \%$ and less than $1 \%$ of $\mathrm{TiO}_{2}$.

The Low-Ti chromites located in the cores of the diamonds differ in composition with those in the rims: $\mathrm{Fe}$ and $\mathrm{Cr}$ are replaced by $\mathrm{Mg}$ and $\mathrm{Al}$ (Fig. 3b) during diamond growth. This differs from the trend found for chromites in Yakutian diamonds where $\mathrm{Mg}$ and $\mathrm{Al}$ are replaced by $\mathrm{Fe}$ and $\mathrm{Cr}$ during growth of diamonds (Bulanova, 1995).

The second Ti-rich group of chromites is rare and is characterized by $\mathrm{Cr}_{2} \mathrm{O}_{3} 40-62 \mathrm{wt} \%, \mathrm{MgO}$ $13-16 \%$ and $\mathrm{TiO}_{2} 1-2.7 \%$ (Fig. 3b). Chromites of similar composition were found in diamonds from River Ranch kimberlites located within the Limpopo Mobile Belt (Fig. 1) (Kopylova et al, 1997).

The Murowa high-Ti group of chromites is richer in $\mathrm{Ga}, \mathrm{Y}, \mathrm{Zr}, \mathrm{Ba}, \mathrm{La}$ and Ce compared to the low-Ti chromite inclusions.

Olivine has compositions typical of diamond inclusions world-wide, with Fo ${ }_{92-94}$ indicative of dunite-harzburgite paragenesis and high concentration of $\mathrm{NiO}(0.25-0.4$ wt.\%). One Sese diamond has olivine $\mathrm{Fo}_{90.5}$ indicative of lherzolitic paragenesis and has an order of magnitude higher content of the trace elements $\mathrm{Na}, \mathrm{K}, \mathrm{Ca}, \mathrm{Ba}, \mathrm{Li}$; $\mathrm{Zr}, \mathrm{Nb}, \mathrm{Y}$; and $\mathrm{La}, \mathrm{Ce}$ compared to the other olivines.

Cr-pyrope G10 harzburgitic garnets were exposed in 7 diamonds, all but one strongly subcalcic, with high Mg\# (85 - 90), very low $\mathrm{Ca}$ contents $(<3.69$ wt. $\% \mathrm{CaO})$, and $\sim 9-17$ wt.\% $\mathrm{Cr}_{2} \mathrm{O}_{3}$ (Fig. 3c). One inclusion with 17.5 wt.\% of $\mathrm{Cr}_{2} \mathrm{O}_{3}$ and 12.8 wt.\% of $\mathrm{CaO}$ belongs to the wehrlite paragenesis (Fig. 3c). This garnet 
contains $1.78 \mathrm{wt} . \% \mathrm{TiO}_{2}$ and is enriched in $\mathrm{Y}, \mathrm{V}$, $\mathrm{Sr}, \mathrm{Cu}$ and $\mathrm{Na}$ compared with other Murowa garnet inclusions.

Murowa and Sese garnet REE patterns generally follow the typical world-wide sinusoidal shape for harzburgitic garnet diamond inclusions (Stachel et al, 2004), but rise to slightly higher in MREE concentrations (Fig. 3d). In comparison, garnets the Murowa peridotite xenoliths display both harzburgitic and flatter lherzolitic trends.

Orthopyroxene ("Opx"), $\mathrm{En}_{91-94}$ in two Sese diamonds, has typical chemistry for Opx diamond inclusions with $0.5-0.86 \mathrm{wt} \% \mathrm{Cr}_{2} \mathrm{O}_{3}, 0.64-0.9 \%$ $\mathrm{Al}_{2} \mathrm{O}_{3}, 0.24-0.76 \% \mathrm{CaO}$, belonging to lherzolitic paragenesis (Stachel and Harris 2008).

Opx inclusions in 6 Murowa diamonds are $\mathrm{En}_{93_{96}}$, and are of harzburgitic affinity. Murowa orthopyroxene diamond inclusions are richer in $\mathrm{Nb}, \mathrm{Ba}$ and have wider range of REE compared to those from other localities.

A $C r$-diopside micro-inclusion was found within an olivine inclusion $(\mathrm{Mg \#} \mathrm{0.93)} \mathrm{in} \mathrm{one}$ diamond. The diopside has $\mathrm{Mg} \# 0.95$, high $\mathrm{Cr}_{2} \mathrm{O}_{3}$ (2.81 wt.\%), and 17.16 wt.\% $\mathrm{CaO}$ and could be of either harzburgitic or lherzolitic paragenesis.

Sulphide inclusions are high $\mathrm{Ni}$ monosulphide solid solution or pentlandites.

Yimengite, a very rare oxide with large ion lithophile elements (LILE), was found in one Sese (Bulanova et al, 2004) and one Murowa diamond. The yimengite shapes and location along diamond growth zones deep inside the hosts prove their syngenetic genesis. Compared with chemistry of yimengite described from kimberlites (Haggerty, 1995), the diamond inclusions contain Al, only $\mathrm{Fe}^{2+}$, no $\mathrm{Fe}^{3+}$ and are enriched in $\mathrm{Mg}$. The occurrence in the Sese yimengite inclusion of low chromium-titanium spinel lamellae similar in composition to the high-Ti chromite inclusions in the diamonds suggests this is the first stage of chemical conversion of chromite into yimengite during mantle metasomatism by a fluid enriched in $\mathrm{Ti}, \mathrm{K}, \mathrm{Ba}$, Sr and LREE.
Armalcolite, another exotic oxide (Fe $\mathrm{Mg}) \mathrm{Ti}_{2} \mathrm{O}_{5}$ (Haggerty, 1995), occurs as a lamella in the rim zone of an olivine inclusion encapsulated in diamond Mur-108.

\section{Eclogitic paragenesis}

Omphacite with $\mathrm{Mg} \# 73,0.65$ wt. $\% \mathrm{TiO}_{2}$ and $\sim 8 \mathrm{wt} . \% \mathrm{Al}_{2} \mathrm{O}_{3}$ was identified in two diamonds only. Chondrite normalized REE patterns of Murowa omphacites occupy a low-concentration part of the REE field for world-wide sources, showing also small positive Eu anomalies.

\section{Central inclusions seeds}

Similar to world-wide data (Bulanova, 1995) Sese and Murowa diamonds contain central inclusions acting as seeds for peridotitic diamond nucleation and growth, mainly olivine and chromite. In several diamonds the seeds are represented by microinclusions of monocrystalline graphite \pm magnesite \pm phlogopite. Carbon isotope composition in one of such diamonds changes from $-2.6 \%$ in the core to $-4.9 \%$ in the rim.

\section{Age of the diamonds}

A published Paleoarchean date for a single sulphide from a Murowa diamond (Smith et al., 2009 ) is consistent with the highly aggregated $\mathrm{N}$ of the diamonds which supports an Archean age for most of the diamonds. A minor younger diamond generation is indicated by those diamonds with weaker $\mathrm{N}$ aggregation and inclusions of yimengite dated at $892 \pm 21$ Ma by ${ }^{40} \mathrm{Ar} /{ }^{39} \mathrm{Ar}$ (Bulanova et al., 2004).

\section{DISCUSSION}

\section{Constraints on diamond origin Mineral inclusion thermobarometry}

Olivine-spinel thermometry (O'Neill and Wall, 1987) on non-touching inclusion pairs 


\section{0 $^{\text {th }}$ International Kimberlite Conference, Bangalore - 2012}

suggests diamond formation at temperatures of $967-1190^{\circ} \mathrm{C}$ (median value $1074^{\circ}$ ) and overlaps the temperature range of $1043-1277^{\circ} \mathrm{C}$ (median $1061^{\circ}$ ) determined on garnet inclusions from Niin-garnet thermometry (Canil, 1999). These results can be fitted to the $40 \mathrm{~mW} / \mathrm{m}^{2}$ geotherm estimated for Murowa and Sese by Smith et al. (2009) from thermobarometry on mantle xenoliths and kimberlite concentrate minerals. This fit implies pressures of 4.2-6.8 GPa, with lithosphere depth slightly exceeding $200 \mathrm{~km}$. However, the lowest olivine-spinel temperatures would fall within the graphite stability field and may suggest the geotherm at the time of diamond formation was cooler than $40 \mathrm{~mW} / \mathrm{m}^{2}$. The mantle xenolith and concentrate geotherm may reflect re-equilibration at hotter temperatures closer to the Cambrian time of kimberlite eruption.

\section{Temperature of diamond formation from FTIR}

Diamond formation temperatures determined from $\mathrm{N}$ concentration and aggregation, based on a mantle residence time of $2.9 \mathrm{Ga}$, are in the range $1120-1180^{\circ} \mathrm{C}$ for most data, with median values of $1136^{\circ} \mathrm{C}$ for both Sese and Murowa. These results, reflecting the effects of temperature over the time of diamond mantle residence, are hotter than the median inclusion temperatures at the time of diamond crystallization.

Centre and rim temperatures for individual diamonds follow the same isotherm, indicating uniform temperature conditions throughout crystal growth. Exceptions are Mur-82 and -83 (Fig. 4). Both Sese and Murowa have two extra smaller temperature populations at ca. $1200^{\circ} \mathrm{C}$ and $1080^{\circ} \mathrm{C}$.

\section{Nature of diamond host}

The relative proportions of olivine, orthopyroxene, and clinopyroxene inclusions in the diamonds (Fig. 5) suggest derivation within a

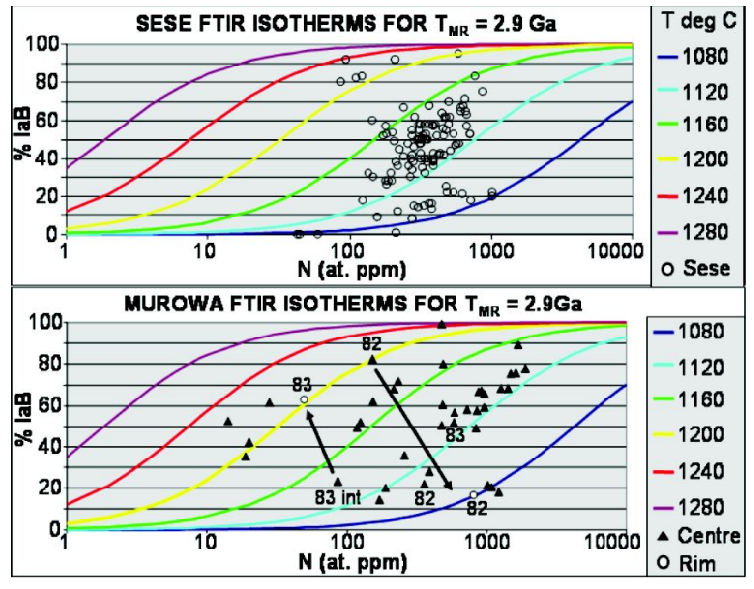

Fig. 4. Sese and Murowa FTIR isotherms for a mantle residence time of $2.9 \mathrm{Ga}$.

depleted olivine-rich harzburgite environment with only about $11 \%$ orthopyroxene and $1 \%$ clinopyroxene. This compares well with the extremely depleted lithospheric mantle represented by the xenolith compositions from the pipes which predominately consist of dunite $(56 \%)$, with lesser amounts of harzburgite $(26 \%)$ and lherzolite (18\%) (Smith et al., 2009). However, chromites and sulphides are the most abundant minerals in the diamonds, (Fig. 5) whereas spinel and sulphides in the xenoliths are only minor in amount and mostly secondary in origin. This dichotomy is well known from other

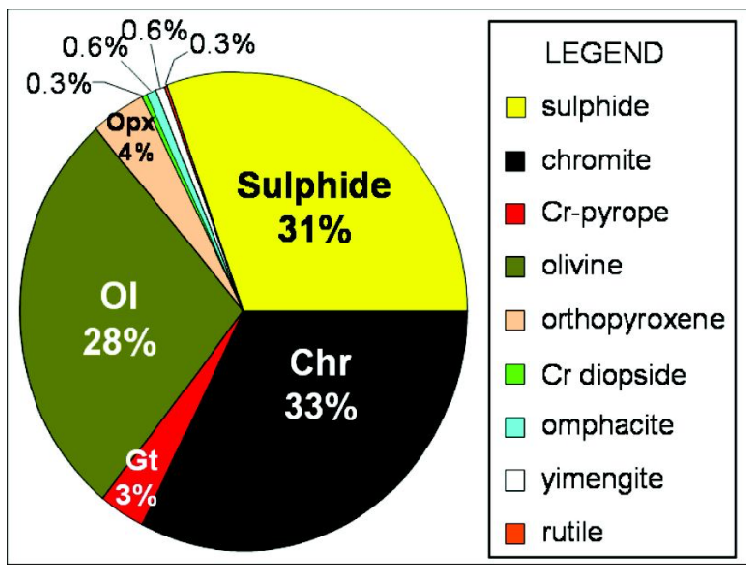

Fig. 5. Mineral inclusion proportions in Murowa and Sese diamonds: the percentage of diamonds with the specified mineral inclusions are shown. 


\section{0 $^{\text {th }}$ International Kimberlite Conference, Bangalore - 2012}

world localities, but has never been fully explained. One possibility would be (i) sequestration and re-crystallization of chromites from harzburgites during the metasomatic stage of diamond growth and (ii) the presence of immiscible sulphide melt itself in the diamondforming metasomatic fluid. This implies that chromite in the peridotitic mantle host is less stable and resistant than under crustal conditions.

An important feature of the mantle host composition is the almost negligible presence of the eclogitic paragenesis, indicating a lack in the diamond source of basalt, either subducted or as mantle melts.

Interpretation of diamond growth history and compositional changes within inclusions

Most of the studied diamonds were formed by tangential growth mechanism as octahedrons in a single event followed by plastic deformation and different degrees of resorption.

Chromites located in core and rims of two such diamonds display distinctive compositional changes. The earlier chromites from the diamond cores are richer in $\mathrm{Fe}$ and $\mathrm{Cr}$. The later chromites from the diamond rims are higher in $\mathrm{Mg}$ and $\mathrm{Al}$. This trend of chromite chemistry suggests the diamonds originated during: (1) a depletion event resulting in the highest $\mathrm{Cr} \#$ of associated chromites, followed by (2) a metasomatic event resulting in the highest $\mathrm{Mg \#}$ of associated chromites.

A very small proportion of the diamonds have experienced two stages of formation, the most prominent example of which is Mur-82 (Fig. $2 \mathrm{~d}$ and 4$)$.

Occurrence of graphite \pm magnesite \pm phlogopite association as inclusion-seeds suggests diamond nucleation in the diamond/graphite equilibrium region from melt/fluid enriched in $\mathrm{CO}_{2}$ and water. The carbon isotope composition of one of such diamonds decreases from $-2.6 \%$ in the core to $-4.9 \%$ in the rim, a trend ascribed by Cartigny et al. (2001) to diamond formation during open system fractionation from $\mathrm{CO}_{2}$ bearing mantle fluids.

\section{Metasomatism during diamond formation}

The composition of mineral inclusions in the dominant diamond population with its high $\mathrm{Cr}$ chromites, strongly subcalcic pyropes with sinusoidal REE patterns depleted in HREE, highly magnesian olivines (Mg\# 0.92-0.94) and enstatites (Mg\# 0.93-0.96) indicate origin in highly depleted harzburgite. On the other hand, chromite, Crpyrope and olivine have elevated concentration of $\mathrm{Y}, \mathrm{Zr}$ and $\mathrm{Ba}$. Chromite and olivine contain such LREE as La and Ce. Olivine has a high level of $\mathrm{Na}, \mathrm{K}$ and $\mathrm{Ca}$. Garnets are higher in MREE compared to their world-wide counterparts. This suggests an even stronger metasomatic process of trace element re-enrichments for Sese and Murowa harzburgitic diamond sources than was proposed for peridotitic inclusions in other diamond occurrences (Stachel et al, 2004).

A Paleoarchean model age for this dominant diamond population was obtained by $\mathrm{Re} / \mathrm{Os}$ dating of a single sulphide inclusion (Smith et al., 2009) and is supported by the highly aggregated $\mathrm{N}$ content of the diamonds.

The yimengite and armalcolite included in several Sese and Murowa diamonds provide strong evidence for a secondary metasomatic enrichment of the diamond source, as does the Ti-enrichment of certain chromites. This younger diamond population has weaker $\mathrm{N}$ aggregation and a possible age of $892 \pm 21 \mathrm{Ma}$ (Bulanova et al., 2004).

\section{CONCLUSIONS}

The results of our study prove the existence of extremely depleted lithospheric mantle peridotite beneath the 538 Ma Murowa and Sese kimberlites, located near the southern edge of the Zimbabwe Craton. This mantle is represented by Paleoarchean dunite-harzburgites with almost complete absence of eclogites, indicating a lack 


\section{0 $^{\text {th }}$ International Kimberlite Conference, Bangalore - 2012}

of basaltic components at the time of diamond formation.

The diamond inclusion suite is dominated by chromite, sulphide and olivine. The abundance of chromite suggests the diamond-forming fluid sequestered it from the peridotitic mantle host, followed by its recrystallisation as syngenetic inclusions as the diamonds grew. The sulphide is assumed to be contained as an immiscible liquid within the diamond-forming fluid. The fluid is indicated to be hydrous and carbonate-rich from the presence in one diamond of magnesite, phlogopite and graphite as a central seed for diamond growth.

Diamond inclusion mineral thermobarometry implies temperature of $1050-1270^{\circ} \mathrm{C}$ and pressures of 4.2-6.8 $\mathrm{GPa}$ indicating a lithospheric keel depth of $\sim 200 \mathrm{~km}$.

Two diamond populations have been revealed. The $\sim 3.4 \mathrm{Ga}$ main diamond population originated during metasomatism (LREE enrichment) of the depleted harzburgite mantle. The diamond formation took place from $\mathrm{CO}_{2}-$ bearing mantle fluids. The $0.89 \mathrm{Ga}$ minor population of diamonds was formed during a second event of intensive metasomatism leading to Ti-enrichment of chromite and development of yimengite and armalcolite. The nature of this metasomatic fluid is uncertain but could be of protokimberlitic/carbonatitic melt infiltrating into the depleted harzburgitic mantle.

\section{ACKNOWLEDGEMENTS}

Rio Tinto PLC is acknowledged for provision of diamond samples and analytical support. Paul Agnew, Ellah Muchemwa and Chris Blake are thanked for their assistance and encouragement.

\section{References}

Bulanova, G.P., 1995. The formation of diamond. Journal of Geochemical Exploration, 53: 1-23.
Bulanova G.P., Muchemwa E., Pearson D.G., Griffin B.J., Kelley S., Klemme S., Smith C.B. 2004. Syngenetic inclusions of yimengite in diamond from Sese kimberlite (Zimbabwe) -evidence for metasomatic conditions of growth. Lithos 77: 181192

Canil, D., 1999.The Ni-in-garnet geothermometer: calibration at natural abundances. Contributions to Mineralogy and Petrology 136:240-246.

Cartigny, P., Harris J.W., Javoy, M. 2001. Diamond genesis, mantle fractionation and mantle nitrogen content a study of $\mathrm{d}^{13} \mathrm{C}-\mathrm{N}$ concentrations in diamonds. EPSL, 185: 85-98.

Haggerty S.H. 1995. Upper mantle mineralogy. Journal of Geodynamics, 4: 331-364.

Kamber, B., Kramers, J.D. Napier, R. Cliff, R.A. \& Rollinson, H.R. 1994. The Triangle Shear Zone, Zimbabwe. revisited: what remains of the Archaean Limpopo orogeny. Precambrian Research, 70: 191213.

Kopylova, M.G., Gurney, J.J., Daniels, L.R.M., 1997. Mineral inclusions in diamonds from the River Ranch kimberlite, Zimbabwe. CMP, 129: 366-384.

O'Neill, H.St.C., Wall, V.J., 1987. The olivineorthopyroxene-spinel oxygen geobarometer, the nickel precipitation curve, and the oxygen fugacity of the Earth's upper mantle. Journal of Petrology 28: 1169-1191.

Smith, C.B., Sims, K., Chimuka, L., Duffin, A., Beard, A.D., and Townend, R., 2004. Kimberlite metasomatism at Murowa and Sese pipes, Zimbabwe. Proc. 8th Int. Kimberlite Conference, Lithos, Vol. 76 (1-4): 219-232.

Smith C.B., Pearson, D.G., Bulanova, G.P, Beard, A.D., Carlson, R.W., Wittig, N., Sims, K., Chimuka L., Muchemwa E., 2009. Extremely depleted lithospheric mantle and diamonds beneath the southern Zimbabwe Craton. Proc. 9th Int. Kimberlite Conference, Lithos, 112S (1-4): 11201132.

Stachel, T., Aulbach, S., Brey G.P., Harris J.W., Leost, I., Tappet R., Viljoen, K.S., 2004. The trace element composition of silicate inclusions in diamonds: a review. Lithos, 77: 1-19.

Stachel, T., Harris, J.W., 2008. The origin of cratonic diamonds - Constraints from mineral inclusions. Ore Geol. Rev., 34: 5-32. 